RPT : RMC

IV -3

February 4, 1946

FLUORESCENT LAIIPS

I. Instroduction

II. Work of the National Bureau of standards on

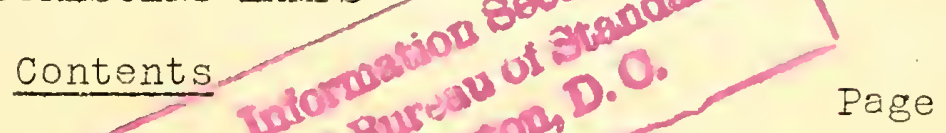

\title{
Fluorescent Lamps
}

III. Description of the Lamps

IV. General Information

$\mathrm{V}$. Does the Fluorescent Lamp Have Any Deleterious Effect on Vision or the Eye?......... 4 VI. Bibliography .. . . . . . . . . . . . 6

\section{Introduction}

The development of fuorescent lamps and their possibilities for general and decorative lighting purposes have brought many requests for information to the Bureau. This letter circular has been prepared to answer such inquiries. It contains information which has been accumulated in answering these letters, but is not an exhaustive treatise on the subject.

II. Work of the National Bureau of Standards on Fluorescent Iamps.

The development of fluorescent lamps by their manufacturers is progressing so rapidly that, although the Bureau has studied the radiation from these Iamps, as discussed in Section $V$, it has as yet made no extensive tests to compare the efficiencies or costs of operation of fluorescent and incandescent lamps. Such information is given by the manufacturers and is referred to below. A letter circular on Fluorescence and Phosphorescence, LC-550, was issued by the Bureau under date of April 1, 1939; it is available, without cost, upon written reuest.

\section{Description of Lamps}

The most commonly used type of fluorescent lamp is made in the form of a tubular bulb with a filament-type electrode sealed in each end. A base, having two pins for making electrical contact in the special sockets used, is cemented onto each end of the tube. A new type, in which the tube is bent to form a circle, is also available. In this form the four contacts are made through a socket at one part of the circle; in some makes this socket can be rotated so that the lamp may be oriented in any position. Another type, characterized by tubes of smaller 
diameter than the older types, is available in various lengths. This type has a single cortact at each end and operates on special autotransformers which differ markedly from the older types in electrical characteristics. These slim fiuorescent lamps are available in either the "hot cathode" or "cold cathode" types of construction:

Many types of electric-discharge.sources of light have long been known, the more common ones being those using neon, mercury, and sodium vapor. The fluorescent lamo is also an electricdischarge source, but of notably different type. It is essentially a meroury-vapor lamp with a smell amount of argon gas to facilitate starting. The electrical characteristics, current density, vapor pressure, and voltage are so reguleted that the resultant discharge produces as much energy as possibie in the ultraviolet region of the spectrum at $253.7 \mathrm{mpl}$. This ultraviclet energy activates the "phosphor", that is, the material with which tre inside of the bulb is coated. The activated phosphor emits energy in the visible region (fluorescence), the spectral composition of the emitted energy depending upon the particular phosphor being used.

G. E。 Inman has published a comprehensive paper giving the

Transactions of the Illuminsting Engineering Society 34,65 (1939).

spectral energy distribution and the trichromatic coefficients (ICI system), as well as the Iuminous efficiencies and physical characteristics of lamps having iliuminant colors designated as blue, green, gold, pink, red, white, and deylight. The phosphors and the color designations given by one of the manufacturers are listed below:

\section{Phosphor}

Calcium tungstate

Magnesium tungstate

Zinc silicate

Zinc beryliium silicate

Cadmium silicate

Cadmium borate
Color Desirration

Blue
Blue-white
Green
Yellow-white
Yollow-pink
Pink

The luminous efficiencies given by Inmen for fiuorescent lamps range from 3 to 70 lumens per watt deperding on the color. The efficiencies of gas-filled, incandescent-filament lamps (common household sizes) vary from about 10 to 17 lumens per watt depending upon the size in watts. The "daylight" and "white" fluorescent lamps most commonly used for illunination purposes have 2 to 3 times the luminous efficiency of the usual incandescent lamps, even when the power (approximately 20 percent of the total power) consurned in the auxiliary is included. 
The "white" lamp manufacturea when Inman published his paper in January 1939 had a color temperature of about $2800^{\circ} \mathrm{K}$. This was changed later to about $3500^{\circ} \mathrm{K}$ and the designation "white" retained. The color temperature of the "daylight" fluorescent lamp is about $6500^{\circ} \mathrm{K}$, which is close to natural daylight from an overcast sky or from sun plus blue sky on a horizontal surface. An intermediate color temperature designated as " $4500^{\circ}$ white" is now available.

\section{General Information.}

The fact that the mercury arc emits energy in the short-wave ultraviolet region of the spectrum known to be harmful to the human eye has supplied the basis for a rumor that the fluorescent lamp itself is harmful. Neasurements made in the Radiometry Section of the National Bureau of Standards have shown, however,

Radiation from Fluorescent Lamps. Technical News Bulletin of the National Bureau of Standards No. 2E6, February 1941. Also Journal of the Optical Society of America 31, 280 (Jarch 194l).

that the harmful energy is used only to activate the phosphor and does not penetrate appreciably the glass tubing, which is highly opaque to it. Therefore, the fluorescent lamp is free from injurious ultraviolet radiant energy.

Fluorescent lamps, in common with all electric-discharge sources, require auxiliary equipment. This auxiliary equipment in general consists of two principal elements: (I) an iron-core choke coil which limits the arc current and (2) a starting switch which momentarily closes and then opens the electrode pre-heating circuit. Each lamp requires a separate auxiliary (some manufacturers mount multiple lamp auxiliaries in a single metal container). Specifically designed auxiliaries are required for each wattage size, each frequency, and each voltage range. A new circuit and auxiliary are now sometines used to obtain instantaneous starting without the momentary preheat period and use of the starter switch. The words "instant start" will appear on both lamps and auxiliaries of this type. Such lemps are not interchangeable with the same size lamp designed for use with a starter switch.

Fluorescent lamps must not be airectIy connected to the electrical circuit. The auxiliary equipment which is designed to operate the lamp is made for operation on the various commercial voltages and frequencies.

Any lamp operated on an alternating-current circuit has a non-uniform light output caused by the cyclic variations in current. With incandescent filament lamps, fiicker is not noticeable, except in low-wattage lamps operated at low frequency (usually helow 50 cycles), because sufficient energy is stored up in the 
glowing filament to bridge the periods when ro current is flowing. In fluorescent lamps, whore pactically no energy is thus stored, the light drops almost to zero along with the current between each half cycie, causing ilicker and stroboscopic effects, particularly in evidence when viewing moving objects (such as rotating machinery and tools in manufacturing plants). Fortunately most of the fluorescent powders used in the se lamps have a slight persistence of glow (phosphorescence) which helps to reduce flicker the reduction being deperident on the chosphor used.

Flicker and stroboscopic effects with fluorescent lamps are most marked where lamps are burred singly, and in such cases little can be done to improve the condition. However, where two or more lamps are housed in a singie unit, or even used close together in individual units, it is possible to minimize flicker considerably by menipulating the current to each lamp so that the high point in the current cycle (also of light output) of one lamp occurs simultanecusly with tine zero point in the current cycle of the other lamp. This out-of-phase condition is realized by burning lamps on two or more phases or by placing an appropriate condenser in the circuit of one or more of the lamps in a given installation. Special auxiliaries which produce tris out-of-phase condition are available for the fixtures wisch use two lamps.

A choke coil such as that in the fluorescent-lamp auxiliary, because of its inductive effects, introduces a low power factor. Electrical engineers use the term "wattless component" for the effect of this inductance. The wattess component does not register on wattmeters or wathour meters but does cause heating in the distribution system. The correction of this power factor is important to the public utility since a low-power-factor load interferes with the efficient operation of the distribution system. The user may inadvertenty. overload a circuit if he neglects to make allowance for the heating caused by the wattless component or the losses in the auxiliary equipnent. There are on the market specially designed capacitors for correcting power factor. These are available both as a separate unit and as en integral part of the auxiliary.

Fixture manufacturers have formed an organization known as Fleur-0-Lier Manufacturers, 2l41-3 Keith Puilaing, Cleveland, Ohio, which will furnish information on firtures designed for use with fluorescent lamos.

\section{Does the Fluorescent Lamp IEve Any Deleterious Effect}

Complaints of eye fatigue from fluorescent lighting seem to have been fairly common. Two of the possible sources of injury or fatigue were mentioned in the last section, namely, harmful ultraviolet energy and licker. Other questions have been raised. 
The matter was considered by the Smaller war Plants Corporation of sufficient importance to justify a letter of inquiry to various authorities. This Bureau's reply, published in Lighting and Lamps 44, p. 14 (February 1944) was as follows:

"I. It is our understanding that fluorescent lamps now being manufactured have less flicker than earlier ones but we have no certain information on tris point. Ir eny case alternations of 120 times per second are too rarid to be noticeable by the eye except for the very special kinds of work where certain stroboscopic effects might be apparent. In goneral, therefore, (a) flickering of fluorescent lights should cause no noticeable fatiguing of the eye nor (b) should it cause any pernanent injury to the eye.

\section{"2. Neither the color nor the temperature of fluorescent} lights should cause any fatigue or injury to the eye. The light spectrum differs from that of daylight chiefly by having the mercury-arc spectrum added. Since the mercury-arc light has itself been widely and successfully used in industry, it is hard to believe that the adaition oI a small part of it can have any important fatiguing effect over and above that which would be due to daylight alone.

"3. No harmful ultraviolet radiant energy is emitted by commercial fluorescent lamps. In this connection see the inclosed copy of article entitled, Radiation from Fluorescent Lamps, published in NBS Technical News Bulletin No. 286, February, 1941.

\section{lights.}

"4. There is nothing inherently wrong with fiuorescent

"5. The eye should have no need to condition itself to fluorescent lights.

"It is probable that, were trouble is experienced by office or factory workers under fluorescent lighting, this trouble is caused by improper instellation of the lighting fixtures resulting in improper distribution of the light rather than by any defect in the light source itself. Incandescent light: also cause fatigue and eye trouble if so installed as to cause glare to the worker or be in his direct line of vision. There is no resson that we know of why fluorescent lights are not as suitable as incandescent lights for general lighting. They are in wide use at this Bureau."

Following this reply are given $r$ eplies from other sources, including the U. S. Public Health Service. The reply of the American Medical Association was published in the June 1944 issue of the same journal. In general these comnents jndicate that most of the trouble resulting from fluorescent iighting has resulted from improper installations and not from any inherent defect in the quality of the light. 
It should further be remembered that during the past four years people have been working long hours on exacting tasks, often at night and under various kinds of mental strain. Nany of them were previously unaccustomed to such kinds of work. It is not surprising that under these circumstances eye trouble was experienced by many workers during the var period.

\section{Bibliography}

The fluorescent lamp is in a state of rapid development and the current literature should be consuited for the latest information. Articles appear in the Illuminating Engineer (formerly Transactions of the Illuminating Engineering Society), published by the Illuminating Engineering Society, 51 Madison Avenue, New York. Copies of this publication may be found in many libraries and separate copies are available from the society. The Electrical World has also published a number of articles of interest on the subject of fluorescent I amps.

Bulletins and pamphlets on fluorescent lamps available for distribution are issued by the General Flectric Company, Nela Park, Cleveland, Ohio; the Westinghouse Electric Corporation, Iamp Division, Bloonfield, New Jersey; Sylvania Ellectric Products Inc., Salem, Nassachusetts; the Consolidated Electric Iamo Company (trade name Champion Lamps), Iynn, Inasachusetts; and other manufacturers.

The following technical articles should be of interest to those seeking information on the history and present status of fluorescent lamps:

I. J. Buttolph and L. B. Johnson, Ultrgviolet radiation and fluorescence, Trans. Ill. Eng. Soc. 31, 2I (1936);

S. Dushman, The search for high-efficiency light sources, J. Opt. Soc. Am. 27, I (1937);

G. E. Inman and R. N. Thayer, Low-voltage fluorescent lamps, Elec. Eng. 57, 245 (1938);

J. A. McDermott, High-voltage gaseous and fluorescent tubes for advertising and architectural lighting, Elec. Eng. 57, 286 (1938);

H. G. Jenkins and C. D. Brown, Fluorescent tube Iighting, G.E.C. Journal 9, 163 (1938);

J.W. Marden, N. C. Beese, and G. Meister, Effect of temperature on fluorescent lamps, Trans. I11. Ing. Soc. 34, 55 (1939);

G. E. Inman, Characteristics of fluorescent lamps, Trans. I1l. Eng. SOC. 34, 65 (1939); 
$\mathrm{IC}-817$

R. N. Thayer and B. T. Barnes, The Dasis for high efficiency in fluorescent lamps, J. Opt. Soc. Am. 29, 13i (1939);

H. M. Sharp and J. F. Parsons, Lighting Cost Comparisons, Electrical World 1l1, E. 998 (April i039);

D. H. Tuck, Fluorescent lighting and air conditioning, Electrical World 111, 1736 (June 1939);

Fluorescent Versus Incandescent Costs, Electrical World, II4, 420 (August 1940);

A. H. Taylor, Irfluence of fluorescent lighting on the colors of decorations and furnishings, Iliuninating Engineering 35 , No. 7, 625 (July 1940);

Myrtle Fahsbender and R. G. Slauer, Fluorescent lamp applications in the home, Illuminating Engineering 35, No. 8, 669

(Septernber 1940);

W. M. Potter and W. G. Darley, The design of luminaries for fluorescent lamps, Illuminating Ingineering 35, No.9, 759 (November 1940);

W. Foulks, The application of continuous source luminaries, Illuminating Engineoring 55, No.9, 786 (November 1940);

O. P. Cleaver, Notes on the effects of fluorescent lighting on certain pigments, Illuminating 표gineering 35, No. 9, 795 (November 1940);

A. E. Parker, Neasurement of illumination from gaseous discharge lamps, Illuminating Engineering 35, No.9, 833 (November 1940);

R. F. Fays and.D.S. Gustin, Alternating current circuits for fluorescent lamps; Illuminating Engineering 35, No. 10, 939 (December 1940);

W. S. Peterson and T. M. Elakeslee, Gaseous tube harmonics in -reference to distribution, Electrical World 115, 302 (January 25, 1941);

M. S. Oldham and Wm. Kunerth, Effect of the size of the particle on the intensity of iliorescence of a phosphor, J. Opt. Soc. Am. 31; 102 (February 194I);

J.W. Marden and N. C. Beese, Ultraviolet excitation of fluorescent compounds, Illuminating Engineering 36, 235 (February 1941);

E. W. Commery, How to use fluorescent lamps and lighting, Interiors, I2 (January 1941); 
A. C. Howle, Cutting interference from fiuorescents, Electrical World 115, 1344 (April 5, 1941);

R. F. Hays, Characteristics of low voltage fiuorescent lamps at high frequencies, IIluminating Engineering 36, 570 (May 1941);

C. C. Mills, Relative costs of industrial light sources, Electrical World 116, 885 (September 20, 1941);

H. L. Logan, The anatomy of visual efficiency, Illuminating Engineering 36, 1057 (December 1841);

J.W. Marden and G. Meister, High and low voltage fluorescent lamps, Illuminating Engineering 36, 1286 (December 1941);

D. P. Caverly, The application of high-voltage fluorescent tubing to lighting problems, IIIuminating Engineering 36, 1298 (December 1941);

M. Iuckiesh and F. K. Moss, Vision and seeine under light from flucrescent lanps, Illuminating Engineering 37, 81 (February 1942);

G. Lippincott, Fluorescent Iighting for interiors, Interiors (December 1941);

B. F. Greenberg, Cost analysis of fluorescent vs incand escent lighting installations, Illuminating Engineering 37, 165 (Narch 1942);

F. C. Winkler, Fundemental facts of fluorescent fixture design, Illuminating Engineering 37, 229 (April 1942);

American recommended proctice of industrial lighting, Illuminating Engineering 37, 279 (Nay 1942);

Procedure for installing "F" lamps on D. C., Flectrical World Il], 1547 (May 2, 1942);

F. S. Kinsey, Problems of fluorescent design and comparative costs, Metropolitan Electrical News, (November 1942);

H. Reinhardt, Group replacement of fluorescent lamps, IIluminating Engineering 38, 179 (April 1943);

W. Phillips, Cold cathode tubes in industrial lighting, Electrical World 119, 1280 (April 17, 1943);

A. E. Reynolds, Cold-catrode fluorescent lighting, Lighting and Lamps (July 1943); 
N. E. Merrill, The importance of starters to fluorescent lamp operation, Iighting and Lamps (July 1943);

J. I. Kilpatrick, An economic evaluation of Iighting systems, Illuminating Ingineering 38, 493 (Noverber 1943);

S. S. Bradforà, Fluorescent in home iighting, Electrical World 121, 126 (January 8, 1844);

R. D. Bradley and $F$. B. Lee, Fluorescent sources at work, Illuminating Engineering 39, 6 (January 1944);

E. A. Iinsday, Brightness of cylindrical fluorescent sources, Illuminating Engineering 39, 23 (Jenuary 1944);

J. C. Sabatini, cold cathode fluorescent -- the new illuminant, Iighting and Lamps (December 1943);

J.W. Bateman, The operation of fluorescent and electric discharge lamps on 25 cycies, Illuminating Engineering 39, 373 (June 1944);

Avoiding radio interference from fluorescent lamp lighting installations, Electrical News and Enci nearing (Toronto) (Nay 1, 1944);

J.W. Bateman, The economics of fluorescent installations, Electrical News and Engineering (Toronto) (Nay 1, 1944);

I.W. Cook, Fluorescent starters, General Electric Review 47 , 37 (Juily 1944);

A. C. Barr, Effect of circuit on F lamp performance, Electrical World, 122, 91 (August 1944);

D. B. Harmon, Lighting and the eye, Illuminating Engineering 38 , 481 (September 1944):

C.W. Kronmilier, Control equipment for discharge type lamps, Illuminating Engineering 39, 849 (Decenber 1944);

H. MoKinlay, Fluorescent lighting, This Week (October I, 1944);

M. Luckiesh and A. H. Taylor, Radiant energy from fluorescent lamps, Illuminating Engineering 40 , 77 (February 1945);

M. Fahsbender, Fluorescent lighting for your future home, Better Homes and Gardens (January 1945);

W. G. Sawyer, Certified fixtures for residences, Electrical World 124, 107 (July 21 , 1945);

W. R. Weise, Cyclic flicker of fluorescent lamps, Electrical World 124, 80 (October 27, 1945). 
